\title{
EFEK PROFITABILITAS. LEVERAGE DAN LIKUIDITAS TERHADAP RETURN SAHAM SYARIAH SEKTOR KEUANGAN DI INDONESIA
}

\author{
Yeni Kartikawati \\ Universitas Islam Zainul Hasan Gengong, Probolinggo Indonesia \\ Email: kartikawatiy@gmail.com
}

\begin{abstract}
Introduction: This study aims to analyze the influence of the company's fundamental factors in the form of ROA, ROE, EPS, NPM, DER and CR. on stock returns of the financial sector listed in the Sharia Securities List.

Methods: The sample of this study was determined using the saturated sampling method, i.e. all of the population became the sample. The research sample consisted of 5 companies with an observation period of 2018-2020 in order to obtain 15 observational data. Data analysis used multiple linear regression analysis.

Result: The results showed that ROA, ROE, EPS, NPM, DER and CR together had a positive and significant effect on stock returns. While partially ROA, ROE, NPM, and CR have no significant effect on stock returns. Only EPS and DER have a positive and significant effect on stock returns. While the most dominant variable affecting stock returns is DER.

Conclusions and suggestions: Subsequent research uses other ratio proxies for Liquidity, Solvency and Profitability. For example, for profitability, you can use the PER ratio, $\mathrm{MBV}$, market ratio and so on. In addition, the sample size that is too minimal should be expanded to other sectors listed on the Islamic Exchange such as the Jakarta Islamic Index and others.
\end{abstract}

Keywords: ROA, ROE, EPS, NPM, DER, CR, Stock Return.

\section{PENDAHULUAN}

Saham merupakan surat berharga yang diterbitkan oleh perusahaan (emiten) yang menyatakan bahwa investor yang memiliki surat berharga tersebut mempunyai hak kepemilikan atas aset-aset perusahaan. ${ }^{1}$ Secara sederhana, saham merupakan bukti kepemilikan sebuah perusahaan. Jadi, ketika investor membeli saham sebuah perusahaan maka investor tersebut adalah salah satu pemilik perusahaan tersebut. Salah satu alasan investor memutuskan untuk melakukan investasi saham adalah untuk mendapatkan keuntungan atas sejumlah saham yang sudah di belinya.

\footnotetext{
${ }^{1}$ Tandelin, Eduardus. 2016. Manajemen Investasi. Tangerang Selatan: Universitas Terbuka. Hal.13
} 
Keuntungan (Return) merupakan faktor pendorong yang memotivasi dalam proses investasi. Keuntungan adalah penghargaan atas investasi yang telah dilakukan ${ }^{2}$. Adadua jenis keuntungan yang diperoleh dari hasil investasi saham, yaitu dividen dan capital gain $^{3}$. Ketika perusahaan memperoleh laba atau keuntungan dari hasil usahanya maka perusahaan tersebut akan membagikan sebagian dari laba tersebut kepada pemegang saham berupa dividen. Capital gain merupakan keuntungan yang dihasilkan dari selisih harga pembelian saham dan harga penjualan saham tersebut. Banyak faktor yang mempengaruhi tingkat keuntungan atau Return saham diantaranya adalah faktor internal perusahaan itu sendiri yaitu faktor fundamental.

Kinerja seperti rasio likuiditas, rasio solvabilitas (leverage), rasio aktivitas, rasio profitabilitas, rasio pertumbuhan dan rasio penilaian perusahaan memiliki pengaruh terhadap Return saham. Untuk memprediksi Return saham tersebut tidak bisa dilakukan dengan asal tebak saja namun investor dapat melakukan analisis laporan keuangan (analisis fundamental) untuk menilai kinerja perusahaan yang akan dipilih untuk berinvestasi.

Analisis fundamental adalah suatu teknis analisis saham yang didasarkan pada kinerja perusahaan dengan menggunakan data-data yang berasal dari laporan keuangan perusahaan, data tersebut di olah untuk menilai apakah perusahaan tersebut memiliki kinerja dan kesehatan yang baik atau tidak. ${ }^{4}$ Untuk menilai kinerja perusahaan tersebut data-data rasio keuangan dari laporan keuangan selanjutnya bisa di analisis menggunakan teknis analisis rasio. Analisis rasio merupakan analisis yang digunakan untuk mengetahui hubungan pos-pos yang ada dalam satu laporan keuangan atau pospos antara laporan keuangan neraca dan laporan rugi laba. ${ }^{5}$

Return saham menjadi hal yang sangat penting menjadi pertimbangan seorang investor dalam berinvestasi. Oleh karena itu, Investor harus melakukan analisis terhadap faktor yang dapat mempengaruhi kondisi perusahaan perusahaan, sehingga dapat meminimalisasi kerugian yang dapat timbul dari adanya fluktuasi pertumbuhan dan perkembangan perusahaan yang bersangkutan. Hal itu disebabkan karena investasi pada saham merupakan investasi yang berisiko karena hargaham dapat naik tetapi juga dapat turun. Ada dua model atau teknik analisis dalam melakukan analisis dan memilih saham, ada dua aspek atau pendekatan dalam penilaian harga saham yaitu analisis fundamental dan analisis teknikal. ${ }^{6}$

Analisis fundamental pada dasarnya adalah melakukan analisis historis atas kekuatan keuangan, dimana proses ini sering juga disebut sebagai analisis perusahaan

\footnotetext{
2 Ekawati, Erni. 2015. Manajemen Keuangan. Tangerang Selatan: Universitas Terbuka. Hal.24

${ }^{3}$ Budiman, Raymond. 2017. Investing is Easy, Teknik Analisa dan Strategi Investasi Saham untuk Pemula. Jakarta: Elex Media Komputindo. Hal.23

${ }^{4}$ Op.Cit. Budiman, Raymond. 2017. Hal.27

${ }^{5}$ Kasmir. 2016. Analisis Laporan Keuangan. Jakarta: Rajawali Pers. Hal. 34

${ }^{6}$ Suad Husnan, 2015. Dasar-Dasar Teori Portofolio dan Analisis Sekuritas. (Edisi 5). Yogyakarta : UPPN STIM YKPN. Indonesia. Hal. 41
} 
(company analysis), sementara itu analisis teknikal merupakan studi yang dilakukan untuk mempelajari berbagai kekuatan yang berpengaruh dipasar saham dan implikasi pada harga saham. Venkatesh dan Tyagi menemukan bahwa analisis fundamental merupakan suatu metode perbandingan saham yang dipadukan dengan analisis tehnikal. ${ }^{7}$ Sreemoyee juga menemukan bahwa analisis fundamental merupakan penilaian yang bermanfaat bagi perilaku investasi sebelum investor memutuskan investasi di pasar saham. ${ }^{8}$ Suresh yang meneliti lingkungan ekonomi, kinerja industri dan kinerja keuangan sebelum membuat keputusan investasi. Hasil penelitian ditemukan bahwa analisis fundamental merupakan alat untuk penilaian sebelum memutuskan investasi saham. ${ }^{9}$ Kumar et.al. menemukan bahwa analisis fundamental merupakan suatu alat startegi dalam memprediksi perilaku investasi perusahaan di masa mendatang. ${ }^{10}$ Voloshyna menyatakan bahwa fundamental merupakan kombinasi terbaik dalam memprediksi perilaku investasi pasar dalam meningkatkan Return saham. ${ }^{11}$

Ada empat variabel independen dari analisis fundamental yang mempengaruhi Return saham dalam penelitian ini, yaitu Return on Asset (ROA), Return on Equity (ROE), Net Profit Margin (NPM), Earnings per Share (EPS), Debt to Equity Ratio (DER), dan Current Ratio (CR). Return on Assets (ROA) sebagai indikator profitabilitas perusahaan. Martono menunjukkan bahwa ROA berpengaruh positif dan signifikan terhadap pengembalian saham. ${ }^{12}$ Sedangkan penelitian dari Atidhira dan Yustina menemukan bahwa ROA tidak berpengaruh terhadap Return saham. ${ }^{13}$

Variabel yang mempengaruhi Return saham adalah Debt to Equity Ratio (DER). Kennedy yang menunjukkan bahwa Rasio Hutang terhadap Ekuitas (DER) tidak memiliki pengaruh signifikan terhadap pengembalian saham, sedangkan di Bhandari (1988) rasio Hutang terhadap Ekuitas (DER) menunjukkan pengaruh signifikan positif terhadap pengembalian saham yang diharapkan. ${ }^{14}$ Analisis fundamental lain yang juga memengaruhi pengembalian saham adalah Earnings per Share (EPS). Atidhira dan Yustina menemukan bahwa bahwa Earnings per Share (EPS) tidak berpengaruh signifikan terhadap Return saham.

${ }^{7}$ Venkatesh, C.K. dan Tyagi, M. 2011. Fundamental Analysis As A Method Of Share Valuation Comparison With Technical Analysis, Bangladesh Research Publication Journal , 5(3), Hal. 167-174

${ }^{8}$ Sreemoyee. 2013. Business Analysis \& Valuation: Using Financial Statements (4ed.). Mason: South-Western Cengage Learning. Hal 12

${ }^{9}$ Suresh. A.S,.2013. A Study on Fundamental and Technical Analysis. International Journal of Marketing, Financial Services \& Management Research ISSN 2277- 3622 Vol.2, No. 5. Hal 23

${ }^{10}$ Kumar, S., dan Warne, D. 2014. Parametric Determinants of Price-Earnings Ratio in Indian Capital Markets. The IUP Journal of Applied Finance, 15(9), Hal. 63-82

${ }^{11}$ Voloshyna, K. 2015. Fundamental Analysis Vs Technical Analysis in The Egyptian Stock Exchange-Empirical Study. International Journal of Business and Management Study-IJBMS,2(2), Hal. 212- 218

12 Arista dan Astohar. 2012. Analisis Faktor-faktor yang Mempengaruhi Return Saham (Kasus pada Perusahaan Manufaktur yang Go Public di BEI periode tahun 2005-2009). Jurnal Ilmu Manajemen dan Akuntansi Terapan, Vol. 3, No. 1, Mei 2012.

${ }^{13}$ Ibid

${ }^{14}$ Kennedy J.S.P. 2003. Analisis Pengaruh dari Return on Asset, Return on Equity, Earnings Per Share, Profit Margin, Asset Turnover , Rasio Leverage dan Debt to Equity Ratio terhadap Return Saham (Studi terhadap Saham-saham yang Termasuk dalam LQ-45 di BEJ Tahun 2001). Tesis tidak dipublikasikan, Program Pascasarjana Universitas Indonesia, Jakarta. Hal.121 
Sedangkan Arista dan Astohar menunjukkan bahwa Earnings per Share (EPS) tidak berpengaruh signifikan terhadap Return saham. ${ }^{15}$

Berdasarkan gap research yang menunjukkan hasil yang tidak konsisten maka maka penelitian ini dilakukan pada perusahaan sub sektor keuangan yang terdaftar dalam Daftar Efek Syariah (DES). Pemilihan kelompok saham sub sektor keuangan syariah ini dikarenakan industri keuangan syariah di Indonesia sedang berkembang pesat akhir-akhir ini. Indonesia di pasar global termasuk dalam sepuluh besar negara yang memiliki indeks keuangan syariah terbesar di dunia (grafik 1). Namun demikian, pertumbuhan keuangan syariah belum dapat mengimbangi pertumbuhan keuangan konvensional. Hal ini dapat dilihat dari pangsa pasar (market share) keuangan syariah yang secara keseluruhan masih di bawah 5\% (Roadmap Pengembangan Keuangan Syariah Indonesia 2018-2020).

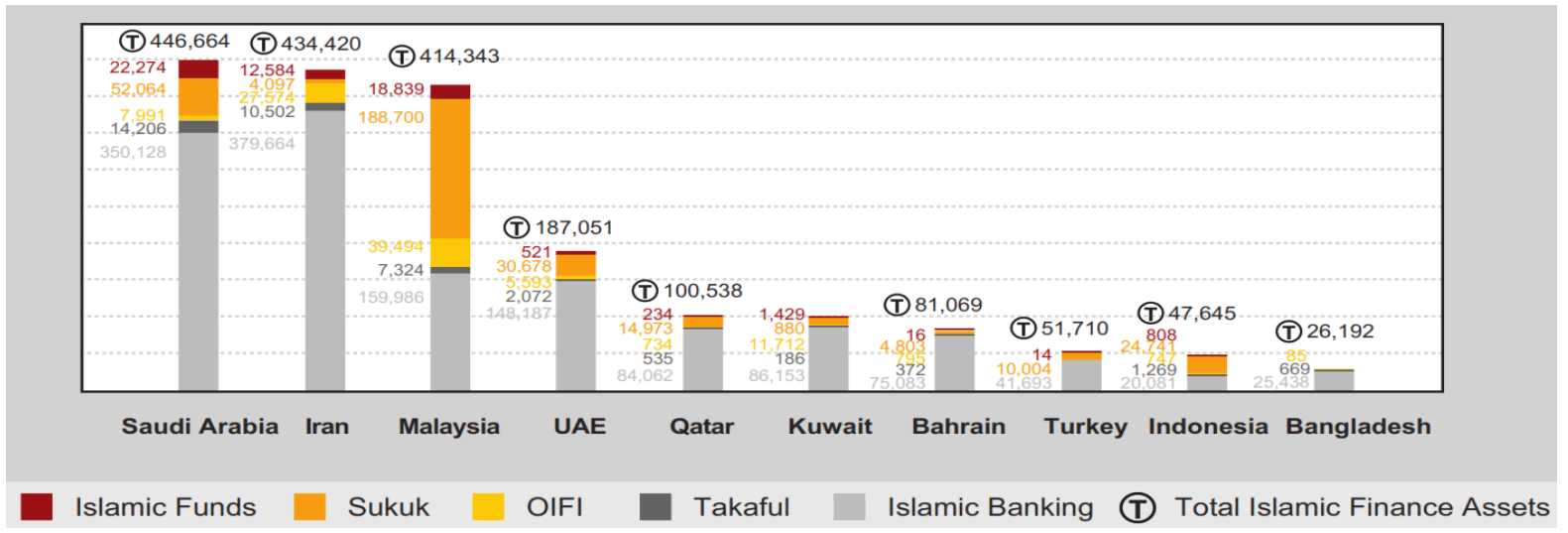

Gambar 1. Negara dengan Aset Keuangan Syariah Terbesar di Dunia

Sumber : Road Map Keuangan Syariah

Jumlah perusahaan saham syariah Indonesia yang terdaftar dalam Daftar Efek Syariah adalah 381. Sementara, jumlah perusahaan sub sektor keuangan syariah Indonesia berada di posisi urutan kedua terakhir yaitu hanya 1,31\% atau 5 perusahaan dari total 381 jumlah perusahaan syariah. Angka tersebut di atas menunjukkan bahwa perusahaan sub sektor keuangan syariah Indonesia masih perlu terus dikembangkan sehingga dapat mengimbangi pertumbuhan saham sektor syariah lainnya.

Pertumbuhan jumlah saham sektor keuangan syariah yang terdaftar dalam Daftar Efek Syariah tegantung hasil penelahaan yang dilakukan oleh OJK per periodik yaitu pada bulan Mei dan bulan November setiap tahunnya, serta penelaahan DES insidentil. Perusahaan dikatakan syariah apabila utang berbasis bunga yang dimiliki oleh emiten dan perusahaan publik tidak lebih dari $45 \%$ dari total aset. Selain itu, pendapatan non halalnya tidak lebih dari $10 \%$ dari total pendapatannya ${ }^{16}$

Indonesia memiliki potensi pengembangan saham syariah yang sangat besar. Hal ini dikarenakan mayoritas penduduk Indonesia adalah muslim. Saham-saham yang

\footnotetext{
${ }^{15}$ Ibid

${ }^{16}$ www.ojk.go.id.
} 
terdaftar di Daftar Efek Syariah merupakan rujukan bagi masyarakat untuk memilih investasi saham syariah. Adanya DES ini, masyarakat mudah untuk mengetahui saham yang termasuk saham syariah. Dewan Syariah Nasional-Majelis Ulama Indonesia (DSNMUI) juga telah menerbitkan Fatwa No. 802011 tentang Penerapan Prinsip Syariah dalam Mekanime Perdagangan Efek Bersifat Ekuitas di Pasar Reguler Bursa Efek. Adanya fatwa DSN-MUI tersebut keyakinan masyarakat bahwa investasi syariah di pasar modal Indonesia sudah sesuai dengan prinsip-prinsip syariah akan meningkat. 17

Saham syariah juga dituntut untuk memperbaiki kinerja perusahaannya, karena Return yang akan di prediksi oleh investor salah satunya adalah bersal dari faktor internal perusahaan itu sendiri yaitu faktor fundamental yang terdiri dari rasio keuangan yang tersaji dalam laporan keuangan perusahaan. Kinerja dan kesehatan perusahaan yang baik akan meningkatkan kepercayaan masyarakat untuk berinvestasi.

Penelitian-penelitian terdahulu banyak dilakukan terhadap obyek kelompok saham non syariah, sementara penelitian yang menganalisis kinerja saham syariah khususnya sub sektor keuangan relatif masih sangat sedikit. Perbedaan penelitian ini dengan penelitian-penelitian sebelumnya terletak pada periode penelitian, objek dan variabel penelitian yang berbeda. Beberapa hasil penelitian terdahulu menunjukkan hasil yang tidak konsisten, maka penelitian ini dilakukan untuk menguji kembali pengaruh beberapa faktor fundamental yang terdiri dari ROA (Return on assets), ROE (Return on equity), EPS (earning per share), NPM (net profit margin), DER (debt to equity ratio) dan Current Ratio (CR) terhadap Return saham. Penelitian ini bertujuan untuk mengetahui untuk mengetahui pengaruh Return On Assets (ROA), Return On Equity (ROE), Earning Per Share (EPS) Net Profit Margin (NPM) Debt To Equity Ratio (DER), Current Ratio (CR) terhadap Return saham sub sektor keuangan dalam Daftar Efek Syariah tahun 2018-2020

\section{TINJAUAN PUSTAKA}

\section{Teori Sinyal (Signaling Theory)}

Teori sinyal mengemukakan tentang bagaimana seharusnya sebuah perusahaan memberikan sinyal kepada pengguna laporan keuangan (pihak eksternal). Dorongan perusahaan untuk memberikan informasi karena terdapat asimetri informasi antara perusahaan dan pihak luar. perusahaan mengetahui lebih banyak mengenai perusahaan dan prospek yang akan datang dari pada pihak luar (investor dan kreditor). Kurangnya informasi bagi pihak luar akan memberikan harga yang rendah untuk perusahaan. Perusahaan dapat meningkatkan nilai perusahaan dengan mengurangi informasi asimetri dengan memberikan sinyal pada pihak luar, berupa informasi keuangan yang dapat mengenai prospek perusahaan yang akan datang.

Teori sinyal (signalling theori) adalah teori yang membahas tentang naik turunnya

\footnotetext{
${ }^{17}$ MUI. Fatwa No. 802011 tentang Penerapan Prinsip Syariah dalam Mekanime Perdagangan Efek Bersifat Ekuitas di Pasar Reguler Bursa Efek
} 
harga di pasar seperti harga saham, obligasi dan sebagainya, sehingga akan memberi pengaruh pada keputusan investor. Tanggapan para investor terhadap sinyal positif dan negatif adalah sangat mempengaruhi kondisi pasar, mereka akan bereaksi dengan berbagai cara dalam menanggapi sinyal tersebut, seperti memburu saham yang dijual atau melakukan tindakan dalam bentuk tidak bereaksi seperti "wait and see" atau tunggu dan lihat dulu perkembangan yang ada baru kemudian mengambil tindakan. Keputusan wait and see bukan sesuatu yang tidak baik atau salah, namun itu dilihat sebagai reaksi investor untuk menghindari timbulnya risiko yang lebih besar karena faktor pasar yang belum memberi keuntungan atau berpihak kepadanya ${ }^{18}$.

Setiap orang baik investor maupun manajer memiliki informasi yang sama tentang prospek suatu perusahaan. Hal ini disebut sebagai informasi simetris (symmetric information). ${ }^{19}$ Pada kenyataannya manajer seringkali memiliki informasi yang lebih baik dibandingkan dengan investor luar. Hal ini disebut sebagai informasi asimetris (asymmetric information), dan memiliki pengaruh penting pada struktur modal yang optimal. Secara garis besar, pengumuman penawaran saham biasanya dianggap sebagai suatu sinyal tentang bagaiman prospek perusahaan menurut penilaian manajemennya.

Informasi merupakan unsur penting yang dibutuhkan oleh investor untuk melakukan investasi. Umumnya informasi tersebut berisikan catatan dan keterangan kondisi perusahaan dimasa lalu dan bagaimana prospeknya dimasa yang akan datang. Informasi yang lengkap dan akurat dibutuhkan oleh investor sebagai alat analisis untuk melakukan investasi. Teori sinyal atau teori pensignalan merupakan dampak dari adanya asimetri informasi. ${ }^{20}$ Teori Sinyal adalah teori yang menjelaskan cara pemberian sinyal perusahaan kepada pihak- pihak yang berkepentingan dengan informasi tersebut. Informasi yang dibutuhkan disajikan pada laporan keuangan yang dibuat perusahaan setiap tahunnya. Sinyal diberikan perusahaan mengenai kinerja perusahaan dalam aspek keuangan maupun non-keuangan dan pencapaian kinerja yang telah diraih oleh manajemen dalam merealisasikan harapan dan keputusan para pemegang saham. Informasi yang diberikan oleh perusahaan umumnya merupakan catatan atau gambaran mengenai kondisi perusahaan pada masa lalu, saat ini, maupun keadaan di masa yang akan datang. Perusahaan dapat memberikan sinyal terkait modal dasar dan rasio-rasio keuangan.

\section{Teori Keagenan (Agency theory)}

Agency theory menggambarkan sebuah hubungan keagenan yang timbul karena adanya sebuah kontrak antara pemilik (principal) dengan manajer(agent)untuk memberikan suatu jasa dan kemudian mendelegasikan wewenang pengambilan keputusan. Principal adalah pemegang saham atau investor dan agent adalah majemen yang mengelola perusahaan.Inti dari hubungan keagenan adalah adanya pemisahan

\footnotetext{
${ }^{18}$ Fahmi, Irham. 2014. Analisis Laporan Keuangan. Cetakan Ke-2. Bandung: Alfabeta Hal. 21

${ }^{19}$ Brigham, E. F., \& Houston, J. F. 2015. Fundamentals of Financial Management (13th edition ed.). Ohio: SouthWestern Cengage Learning. Hal.184-185

${ }^{20}$ Ibid
} 
fungsi antara kepemilikan di investor dan pengendalian di pihak manajemen saham atau investor dan agent adalah majemen yang mengelola perusahaan. Secara khusus teori keagenan membahas tentang adanya hubungan keagenan, dimana suatu pihak tertentu (pricipal) mendelegasikan pekerjannya kepihak lain (agent) yang melakukan pekerjaan. ${ }^{21}$ Agency theory (teori keagenan) merupakan suatu kondisi yang terjadi pada suatu perusahaan dimana pihak manajemen sebagai pelaksana yang disebut lebih jauh sebagai agen dan pemilik modal (owner) sebagai prinsipal membangun sebuah kontrak kerjasama yang disebut dengan "nexus of contract", kontrak kerjasama ini berisi kesepakatan-kesepakatan yang menjelaskan bahwa pihak manajemen perusahaan harus bekerja secara maksimal untuk memberi kepuasan yang maksimal seperti profit yang tinggi kepada pemilik modal (owner). ${ }^{22}$

Manajer dalam hubungan keagenan merupakan pihak yang memiliki informasi penuh yang ada didalam perusahaan, dimulai dari lingkungan kerja, kapasitas diri, dan prospek perusahaan dimasa yang akan datang. Tetapi terkadang ada saja informasi mengenai perusahaan yang tidak diungkapkan oleh manajer kepada investor. Untuk mengurangi hal tersebut dibutuhkan pengawasan dan pengendalian untuk memastikan apa yang dilakukan oleh manajer telah sesuai dengan ketentuan yang berlaku didalam perusahaan. Pengawasan dan pengendalian ini membutuhkan biaya yang biasa disebut sebagai agency cost. Agency cost digunakan untuk membiayai kegiatan pengawasan dan pengendalian terhadap perilaku manajer agar tidak menyimpang dan sesuai dengan apa yang diharapkan oleh pemegang saham. Agency cost adalah biaya yang timbul karena perusahaan menggunakan utang dan melibatkan hubungan antara pemilik perusahaan (pemegang saham) dan kreditor. ${ }^{23}$ Jika perusahaan menggunakan utang ada kemungkinan pemilik perusahaan melakukan tindakan yang merugikan kreditor. Misalnya, perusahaan melakukan investasi pada proyek-proyek yang berisiko tinggi hal ini dapat merugikan kreditor.

Konflik antara manajer dan pemegang saham bagi perusahaan yang dihadapi mengacu pada kesukaran investor untuk mendeteksi dana yang diinvestasikan digunakan manajemen untuk pendanaan kegiatan yang kurang menguntungkan ${ }^{24}$. Teori ini mengasumsikan bahwa agen lebih banyak mendapatkan informasi mengenai kapasitas diri, lingkungan kerja, dan perusahaan secara keseluruhan dibandingkan dengan prinsipal sehingga terjadi peluang manajemen melakukan manajemen laba, manajemen laba tersebut biasanya dilakukan oleh manajer untuk meningkatkan Return saham.

${ }^{21}$ Noor, Juliansyah. 2015. Metodologi Penelitian. Jakarta : Prenada Group..Hal.31

22 Op.Cit Fahmi. 2014. Hal. 21

${ }^{23}$ Dermawan, Deni. 2014. Metode Penelitian Kuantitatif. Cetakan Kedua. Bandung: PT. Remaja Rosdakarya Hal. 273

${ }^{24}$ Tumonggor, Mutiara. Sri Murni dan Rate, Paulina Van. 2017. Analisis Pengaruh Current Ratio, Return On Equity, Debt To Equity Ratio dan Growth Terhadap Return Saham Pada Cosmetics And Household Industry Terdaftar Di Bei Periode 2010-2016. Jurnal EMBA Vol.5 No.2 Juni 2017, Hal. 2203 - 2210 


\section{Return Saham}

Saham merupakan surat berharga yang diterbitkan oleh perusahaan (emiten) yang menyatakan bahwa investor yang memiliki surat berharga tersebut mempunyai hak kepemilikan atas aset-aset perusahaan. ${ }^{25}$ Secara singkat, saham dapat didefinisikan sebagai tanda penyertaan atau kepemilikan seseorang atau badan dalam suatu perusahaan. Keuntungan (Return) merupakan faktor pendorong yang memotivasi dalam proses investasi. Keuntungan adalah penghargaan atas investasi yang telah dilakukan ${ }^{26}$ Tujuan utama investor melakukan investasi adalah untuk mendapatkan keuntungan atau Return. Menurut Budiman (2017:9), terdapat dua jenis keuntungan yang diperoleh dari hasil investasi saham, yaitu dividen dan capital gain. ${ }^{27}$ Ketika perusahaan memperoleh laba atau keuntungan dari hasil usahanya maka perusahaan tersebut akan membagikan sebagian dari laba tersebut kepada pemegang saham berupa dividen. Capital gain merupakan keuntungan yang dihasilkan dari selisih harga pembelian saham dan harga penjualan saham tersebut.

Alasan orang berinvestasi adalah untuk memperoleh keuntungan atau Return. Dalam konteks manajemen investasi, perlu dibedakan antara Return yang diharapkan (expected Return) dan Return yang terjadi (realized Return). Return yang diharapkan merupakan tingkat Return yang diantisipasi investor di masa yang akan dating. Sedangkan Return yang terjadi atau Return actual merupakan tingkat Return yang telah benar-benar diperoleh investor. Perbedaan antara Return yang diharapkan dengan Return yang benar-benar diterima (Return aktual) merupakan risiko yang harus dipertimbangkan dalam proses investasi 28 .

Teori CAPM hanya menggunakan 1 faktor saja untuk mengukur risiko yaitu koefesien beta suatu sekurtitas. ${ }^{29}$ Sedangkan hubungan antara resiko dan keuntungan bisa saja lebih kompleks dimana keuntungan yang diperoleh dari suatu saham bisa saja merupakan fungsi dari beberapa faktor. Sedangkan terori APT bisa memasukkan sejumlah faktor risiko, sehingga keuntungan yang disyaratkan dari suatu saham bisa saja merupakan fungsi dari dua, tiga, empat atau lebih faktor.

Ada beberapa faktor yang mempengaruhi Return saham seperi faktor makro, fundamental, dan faktor pasar. Faktor makro berpengaruh secara lokal terhadap obyek investasi, sehingga yang perlu dilakukan kajian lebih lanjut adalah faktor fundamental dan faktor pasar. Hal ini dikarenkan faktor fundamental berhubungan dengan kinerja perusahaan emiten, sedangkan faktor pasar berhubungan dengan kinerja saham. Menurut teori pasar Pengukuran Return dapat dihitung dengan:

\footnotetext{
${ }^{25}$ Loc.Cit. Tandelilin 2016. Hal. 74

${ }^{26}$ Ekawati, Erni. 2015. Manajemen Keuangan. Tangerang Selatan: Universitas Terbuka. Hal.54

${ }^{27}$ Loc.Cit Budiman. 2017. Hal. 79

${ }^{28}$ Loc.Cit. Tandelilin 2016. Hal. 82

${ }^{29}$ Op.Cit. Ekawati, Erni. 2015. Hal.62
} 


$$
\text { Rit }(\%)=\frac{\left(\mathrm{P}_{i t}-\mathrm{Pit}-1\right)}{\mathrm{P}_{\mathrm{it}}-1} \times 100 \%
$$

Rit $\quad=$ tingkat keuntungan saham I pada periode $\mathrm{t}$.

Pit = harga penutupan saham I pada periode $t$ (periode penutupan/akhir).

Pit-1 = harga penutupan saham I pada periode sebelumnya (awal).

\section{Saham Sektor Keuangan dalam Daftar Efek Syariah (DES)}

Peraturan Otoritas Jasa Keuangan Nomor 15 Tahun 2015 tentang Penerapan Prinsip Syariah di Pasar Modal, Pasal 3 menjelaskan bahwa efek memenuhi Prinsip Syariah di Pasar Modal sehingga menjadi Efek Syariah apabila: oleh Otoritas Jasa Keuangan, tidak bertentangan dengan Prinsip Syariah di Pasar Modal.

Berdasarkan penjelasan di atas dapat disimpulkan bahwa saham syariah merupakan efek berbentuk saham yang kegiatan usaha perusahaannya tidak bertentangan dengan prinsip syariah di pasar modal.

Keputusan Ketua Badan Pengawas Pasar Modal dan Lembaga Keuangan Nomor: Kep-208/Bl/2012 Tentang Kriteria dan Penerbitan Daftar Efek Syariah (DES) menjelaskan bahwa Daftar Efek Syariah (DES) adalah kumpulan efek yang tidak bertentangan dengan Prinsip-prinsip Syariah di Pasar Modal, yang ditetapkan oleh Bapepam dan LK atau diterbitkan oleh Pihak Penerbit Daftar Efek Syariah.

Berdasarkan laporan keuangan emiten dan perusahaan publik yang berakhir pada tanggal 31 Desember 2017, hasil telaah Dewan Komisioner Otoritas Jasa Keuangan yang dituangkan dalam Keputusan Dewan Komisioner Otoritas Jasa Keuangan Nomor KEP-24/D.04/2018 tentang Daftar Efek Syariah, terdapat 381 perusahan yang terdaftar dalam Daftar Efek Syariah yang terdiri dari 11 perusahaan sektor pertanian; 31 perusahaan sektor pertambangan; 55 perusahaan sektor pertambangan industri dasar dan kimia; 28 perusahaan sektor aneka industri; 35 perusahaan sektor industri barang konsumsi; 56 perusahaan sektor properti, real estate dan konstruksi bangunan; 45 perusahaan sektor infrastruktur, utilitas dan transportasi; 5 perusahaan sektor keuangan; 102 perusahaan sektor perdagangan, jasa dan investasi; 4 perusahaan sektor publik; 9 perusahaan tidak listing. Berikut daftar perusahaan sektor keuangan dalam Daftar Efek Syariah (DES):

Tabel 1. Sektor Keuangan Syariah di Indonesia

\begin{tabular}{|c|c|c|}
\hline No & Kode Saham & Nama Penerbit Efek \\
\hline 1 & BTPS & $\begin{array}{c}\text { PT. Bank Tabungan Pensiunan } \\
\text { Nasional Syariah Tbk }\end{array}$ \\
\hline 2 & BRIS & PT. BRI Syariah Tbk \\
\hline 3 & HADE & PT. Himalaya Energi Perkasa Tbk \\
\hline
\end{tabular}




\begin{tabular}{|c|c|c|}
\hline 4 & JMAS & $\begin{array}{c}\text { PT. Asusransi Jiwa Syariah Jasa } \\
\text { Mitra Abadi Tbk }\end{array}$ \\
\hline 5 & PNBS & PT. Bank Panin Syariah Tbk \\
\hline
\end{tabular}

\section{Pengaruh Profitabilitas Terhadap Return Saham Syariah di Indonesia}

Profitabilitas dalam penelitian ini diukur dengan Return On Assets (ROA), Return On Equity (ROE), Earning Per Share (EPS), Net Profit Margin (NPM), Current Ratio (CR) dan Debt to Equity Ratio (DER) dengan Return Saham. Return on Assets (ROA) akan memperlihatkan berapa besar keuntungan yang akan didapat dari aset yang dimiliki perusahaan ${ }^{30}$. Return on Assets (ROA) merupakan rasio yang digunakan untuk mengukur kemampuan dari modal yang diinvestasikan dalam keseluruhan aktiva untuk menghasilkan keuntungan netto ${ }^{31}$ Return on Assets (ROA) menggambarkan perputaran aktiva diukur dari volume penjualan. Semakin besar rasio ini semakin baik. Hal ini berarti bahwa aktiva dapat lebih cepat berputar dan meraih laba. 32

Return on Assets (ROA) sebagai indikator profitabilitas perusahaan. ROA merupakan faktor internal yang digunakan untuk mengukur efektivitas perusahaan dalam menghasilkan laba dengan penggunaan aset yang dimiliki ${ }^{33}$ Adanya peningkatan pengembalian aset menunjukkan seberapa baik aset dikelola oleh perusahaan untuk mendatangkan keuntungan bagi setiap satu dolar aset yang telah diinvestasikan ke perusahaan $^{34}$ Saputro menunjukkan bahwa ROA berpengaruh positif dan signifikan terhadap pengembalian saham. ${ }^{35}$ Dengan demikian, semakin tinggi nilai ROA suatu perusahaan maka semakin tinggi Return saham, sehingga hubungan ROA dengan Return saham dapat dihipotesiskan, yaitu:

H1 : ROA berpengaruh positif terhadap Return saham

Return on Equity (ROE) menunjukkan berapa persen diperoleh laba bersih bila diukur dari modal pemilik. Semakin besar semakin bagus. ${ }^{36}$ Return on Equity (ROE) digunakan untuk mengukur kemampuan modal sendiri untuk menghasilkan keuntungan bagi seluruh pemegang saham, baik saham biasa maupun saham preferen $^{37}$ Return on

30 Filbert, Ryan \& Prasetya, William. 2017. Investasi Saham ala Fundamentalis Dunia. Jakarta: Elex Media Komputindo. Hal.115

${ }^{31}$ Sujarweni, V.W. 2017. Analisis Laporan Keuangan, Teori, Aplikasi, dan Hasil Penelitian. Yogyakarta: Pustaka Baru Press. Hal. : 65

32 Harahap, S.S. 2015. Analisis Kritis atas Laporan Keuangan. Jakarta: Rajawali Pers. Hal. 305

${ }^{33}$ Yustini, Santi, Yusar Sagara, dan Anis Saputri.2018. The Effect Of Profitability, Value, Size and Managerial Discretion On Disclourse Of Stock Return. Akutabilitas Ilmu Akuntansi. Volume 11 No 1. Hal.4

34 Aryono, Yokobus dan Isworo, Sri Ediningsih. 2009. Pengaruh Right Issue Terhadap Kinerja Keuangan Pada Perusahaan Yang Terdaftar di Bursa Efek Indonesia”, Call For Paper Hasil - Hasil Penelitian Dosen dan Seminar Nasional, hal $310-328$.

35 Saputro, Retno. 2018. Pengaruh Return On Assets, Debt To Equity Ratio, dan Current Ratio Terhadap Return Saham Pada Perusahaan Manufaktur Yang Terdaftar di Bursa Efek Indonesia Periode 2011-2015. Jurnal Akuntansi Universitas Maritim Raja Ali Haji. Hal. 121

${ }^{36}$ Loc.cit.. Hararap, 2015.Hal. 41

${ }^{37}$ Loc.cit. Sujarweni. 2017. Hal. 65 
Equity (ROE) digunakan untuk mengukur laba bersih sesudah pajak dengan modal sendiri. Rasio ini menunjukkan efesiensi penggunaan modal sendiri. Semakin tinggi rasio ini, semakin baik. Artinya posisi pemilik perusahaan semakin kuat, demikian pula sebaliknya ${ }^{38}$. Return on Equity (ROE) merupakan rasio yang menunjukkan berapa persen diperoleh laba bersih bila diukur dari modal pemilik. Juwita menyatakan bahwa ROE berpengaruh terhadap Return saham. ${ }^{39}$ Febriawan menemukan bahwa ROE berpengaruh positif terhadap Return saham. ${ }^{40}$

Semakin tinggi ROE, maka semakin efisien dan efektif manajemen perusahaan atau dengan kata lain baiknya kinerja perusahaan tersebut sehingga mempengaruhi minat investor dalam berinvestasi pada perusahaan yang mengakibatkan tingginya penawaran dan tingginya Return saham. ${ }^{41}$ Dengan demikian, semakin tinggi nilai ROE suatu perusahaan maka semakin tinggi Return saham, sehingga hubungan ROE dengan Return saham dapat dihipotesiskan, yaitu:

H2 : ROE berpengaruh positif terhadap Return saham

Earning Per Share (EPS) merupakan rasio yang menunjukkan berapa besar kemampuan per lembar saham menghasilkan laba. Earning Per Share (EPS) digunakan untuk mengukur keberhasilan manajemen dalam mencapai keuntungan bagi pemegang saham $^{42}$

EPS adalah indikator yang baik dari profitabilitas perusahaan dan banyak digunakan oleh pengguna laporan keuangan ${ }^{43}$ Perolehan per Saham (EPS) adalah total pendapatan perusahaan atau laba bersih dikurangi saham preferensi dan dividen kemudian dibagi dengan saham tertimbang yang beredar. High Earnings per Share (EPS) adalah sinyal positif untuk harga saham, karena menarik investor lebih dari jika nilainya rendah ${ }^{44}$ Atidhira dan Yustina menemukan bahwa EPS berpengaruh psoitif terhadap Return saham. ${ }^{45}$ Dengan demikian, Semakin tinggi nilai EPS, kesejahteraan pemegang saham meningkat, tingkat

${ }^{38}$ Loc.cit.. Kasmir. 2016. Hal. 62

${ }^{39}$ Ichsani, Sakina dan Agatha Rinta Suhardi. 2015. The effect of Return On Equity (ROE) and Return on Investment on Trading Volume. Global Conference on Business and Social Science-2015, GCBSS-2105. Nd. Hal.5

${ }^{40}$ Febriawan, M \& Santosa, PW. 2017. Return Saham Dan Faktor Fundamental Pada Pra Krisis Ekonomi Global 2008 Di Bursa Efek Indonesia. Journal of Economics and Business Aseanomics (JEBA) Universitas YARSI Vol.2 No.2 Juli-Desember. Hal. 32-248.

41 Jhony, Kurniawan, Yohanes .2013. Analisis Pengaruh Earning Per Share (EPS), Debt To Equity Ratio (DER), Return On Asset (ROA), Return On Equity (ROE) Terhadap Return Saham (Studi Empirik Pada Perusahaan Real Estate Dan Property Yang Terdaftar Di Bursa Efek Indonesia (BEI) Dalam Pengamatan 2008 - 2011) Jurnal Akuntansi, Bandung : Universitas Widyatama.Hal. 21-35

${ }^{42}$ Loc.cit. Kasmir 2016. Hal. 207

${ }^{43}$ Kieso et al., 2011. Intermediate Accounting. Jilid.1 Edisi 12. Jakarta. Erlangga. Hal. 42 Lestari, W.D. \& Dewi, Rosita. 2018. Pengaruh Return On Asset (ROA), Debt To Equity Ratio (DER), Priceto Book Value (PBV), Dan Price Earning Ratio (PER) Terhadap Return Saham (Studi Pada Perusahaan Yang Tercantum Dalam LQ45 di BEI Tahun 2014-2016). Posiding, Universitas Muhamdiyah, SurakartaHal.23

${ }^{45}$ Atidhira, Agung Tri dan Yustina, Andi 2017. The Influence of Return on Asset, Debt to Equity Ratio, Earnings per Share, and Company Size on Share Return in Property and Real Estate Companies. AAF (Journal of Applied Accounting and Finance). Vol. 1. No. 2, Hal 128-146 
pengembalian yang tinggi, sehingga hubungan EPS dengan Return saham dapat dihipotesiskan, yaitu:

H3 : EPS berpengaruh positif terhadap Return saham

Profit margin digunakan untuk mengukur margin laba atas penjualan. Cara pengukuran rasio ini adalah dengan membandingkan laba bersih setelah pajak dengan penjualan bersih. 46 Profit margin merupakan angka yang menunjukkan berapa besar persentase pendapatan bersih yang diperoleh dari setiap penjualan. Semakin besar rasio ini semakin baik karena dianggap kemampuan perusahaan dalam mendapatkan laba cukup tinggi. 47 Darmawati (2017) menemukan bahwa NPM berpengarih terhadap Return saham. Dengan demikian, semakin tinggi nilai Profit Margin suatu perusahaan maka semakin tinggi Return saham, ${ }^{48}$ sehingga hubungan Profit Margin dengan Return saham, sehingga dapat dihipotesiskan, yaitu:

H4 : Profit Margin berpengaruh positif terhadap Return saham.

\section{Pengaruh Leverage Terhadap Return Saham Syariah di Indonesia}

Debt to Equity Ratio (DER) merupakan rasio yang digunakan untuk menilai utang dengan ekuitas. DER digunakan untuk mengetahui berapa besar untung yang dimiliki perusahaan bila dibandingkan dengan ekuitasnya. Semakin besar DER, maka semakin sempit keleluasan perusahaan untuk melakukan pendanaan dengan utang ${ }^{49}$. Debt to Equity Ratio (DER) menunjukkan proporsi relatif dari hutang dan ekuitas yang digunakan untuk membiayai aset perusahaan, dan rasio Debt to Equity Ratio (DER) yang tinggi mencerminkan risiko solvabilitas perusahaan yang relatif tinggi dan sebagai akibatnya, investor cenderung menghindari perusahaan dengan hutang tinggi atau perusahaan yang memiliki DER tinggi.

Beberapa bukti empiris tentang efek terhadap pengembalian saham menunjukkan DER dalam penelitian yang dilakukan oleh Kennedy yang menunjukkan bahwa Rasio Hutang terhadap Ekuitas (DER) tidak memiliki pengaruh signifikan terhadap pengembalian saham, sedangkan Saputro menunjukkan pengaruh signifikan positif terhadap pengembalian saham yang diharapkan. Dengan demikian, semakin tinggi nilai DER suatu perusahaan maka semakin rendah Return saham, ${ }^{50}$ sehingga hubungan DER dengan Return saham dapat dihipotesiskan, yaitu:

H5 : DER berpengaruh positif terhadap Return saham.

\section{Pengaruh Rasio Likuiditas Terhadap Return Saham Syariah di Indonesia}

\footnotetext{
${ }^{46}$ Loc.cit. Kasmir, 2016. Hal. 199

${ }^{47}$ Loc.cit.arahap, 2015. Hal. 304

${ }^{48}$ Bur, F.I., Munthe, I.L.S \& Ratih, A.E. 2018. Pengaruh Return On Equity, Debt To Equity Ratio, Price Earning Ratio dan Beta terhadap Return Saham Perusahaan Manufaktur Sektor Industri Food dan Beverages di Bursa Efek Indonesia Tahun 2013-2016. Artikel Fakultas Ekonomi UMRAH, Agustus, Hal. 1-16

${ }^{49}$ Loc. cit. Filbert dan Prasetya, 2017. Hal.47

${ }^{50}$ Loc. cit Saputro. 2018. Hal. 81
} 
Rasio likuiditas yaitu rasio yang mengukur kemampuan perusahaan memenuhi kewajiban jangka pendek menggunakan aktiva lancar; rasio solvabilitas yaitu rasio yang mengukur kemampuan perusahaan untuk memenuhi kewajiban financialnya baik jangka pendek maupun jangka panjang apabila sekiranya perusahaan dilikuidasi; rasio profitabilitas yaitu rasio yang mengukur kemampuan perusahaan dalam menghasilkan laba dikaitkan dengan penjualan, total aktiva maupun modal sendiri; dan rasio pasar yaitu rasio yang mengukur harga pasar saham relatif terhadap nilai bukunya.

Rasio likuiditas dalam penelitian ini diproxikan dengan Current Ratio (CR) yaitu suatu cara untuk menguji tingkat proteksi yang di peroleh pemberi pinjaman jangka pendek yang diberikan oleh perusahaan untuk mendanai kegiatan operasional perusahaan sehingga hubungan Current Ratio dengan Return saham dapat dihipotesiskan, yaitu:

H6 : Current Ratio berpengaruh positif terhadap Return saham

\section{HASIL DAN PEMBAHASAN}

Pasar modal syariah secara resmi diluncurkan pada tanggal 14 Maret 2003 bersamaan dengan penandatanganan MOU antara BAPEPAM-LK dengan Dewan Syariah Nasional - Majelis Ulama Indonesia (DSN - MUI). Walaupun secara resmi diluncurkan pada tahun 2003, namun instrumen pasar modal syariah telah hadir di Indonesia pada tahun 1997. Hal ini ditandai dengan peluncuran Danareksa Syariah pada 3 Juli 1997 oleh PT. Danareksa Investment Management. Selanjutnya Bursa Efek Indonesia bekerjasama dengan PT. Danareksa Investment Management meluncurkan Bursa Efek Syariah pada tanggal 3 Juli 2000 yang bertujuan untuk memandu investor yang ingin menanamkan dananya secara syariah. Dengan hadirnya indeks tersebut, maka para pemodal telah disediakan saham-saham yang dapat dijadikan sarana berinvestasi dengan penerapan prinsip syariah.

Deskriptif statistik menjelaskan besarnya nilai rata-rata, deviasi standar, nilai minimum, dan nilai maksimum untuk variabel-variabel penelitian kecuali variabel Dummy (tipe industri dan usia). Hasil statistik deskriptif disajikan pada Tabel 4.1. 
Ar-Ribhu: Jurnal Manajemen dan Keuangan Syariah

Volume 2, No.2, Desember 2021, ISSN (Online): 2774-5570

Tabel 2. Hasil Deskriptif Statistik

\begin{tabular}{|l|l|l|l|l|}
\hline Variabel & Minimum & Maximum & Mean & Std. Deviation \\
\hline Return Saham (Y) & $-0,46$ & 4,29 & 0,50 & 1,24 \\
\hline ROA $(\mathrm{X} 1)$ & $-0,11$ & 0,07 & 0,01 & 0,04 \\
\hline ROE $(\mathrm{X} 2)$ & $-0,45$ & 0,30 & $-0,16$ & 0,91 \\
\hline EPS $(\mathrm{X} 3)$ & $-0,97$ & 1,91 & 0,31 & 0,65 \\
\hline NPM $(\mathrm{X} 4)$ & $-0,70$ & 3,30 & 0,22 & 0,88 \\
\hline DER $(\mathrm{X} 5)$ & 0,00 & 0,84 & 0,27 & 0,27 \\
\hline CR $(\mathrm{X} 6)$ & 0,00 & 0,76 & 0,11 & 0,21 \\
\hline
\end{tabular}

Berdasarkan Tabel 2 menunjukkan deskriptif statistik masing-masing variabel penelitian. Return saham mempunyai nilai rata-rata dari hasil uji statistik deskriptif adalah sebesar 0,50 Standar deviasi sebesar 1,24 yang menunjukkan tingkat persebaran data semakin menjauhi rata-rata. Nilai terendah sebesar $-0,46$ tahun dan nilai tertinggi sebesar 4,29. Hal ini berarti Return saham memiliki rata-rata sebesar 0,50 dengan standar deviasi sebesar 1,24. Nilai ini menunjukkan bahwa data semakin menjauhi nilai rata-rata dan variasi penyebarannya semakin besar. Adanya nilai Return saham yang menjauhi rata-rata menunjukkan bahwa nilai Return saham perusahaan sampel cenderung besar karena nilai Return saham perusahaan sampel berada di atas nilai rata-rata sebesar 0,50.

Nilai rata-rata ROA negatif sebesar $-0,01$ atau 1\%. Standar deviasi 0,04 atau 4\% yang berarti ukuran penyebaran data ROA ini cukup besar. Hal ini didukung nilai standar deviasi yang semakin menjauhi nilai rata-rata dan ukuran penyebarannya semakin besar. Nilai terendah ROA sebesar $-0,11$ atau $11 \%$ dan nilai tertinggi ROA sebesar 0,07 atau $7 \%$. Perusahaan yang menjadi sampel penelitian cenderung berukuran besar yang ditunjukkan dengan nilai tertinggi dan standar deviasi yang semakin besar dari nilai ratarata.. Hal itu mengindikasikan bahwa ROA sampel berada di atas rata-rata atau menjauhi rata-rata sehingga menunjukkan bahwa ROA cenderung berukuran besar.

Nilai rata-rata dari hasil uji statistik deskriptif untuk variabel ROE adalah sebesar $-0,16$ ata $16 \%$. Nilai terendah variabel ROE sebesar $-0,45$ atau $45 \%$ dan nilai tertinggi sebesar 0,30 atau $30 \%$. Hal ini berarti nilai standar deviasi yang mendekati nilai rata-rata dan ukuran penyebaran data yang semakin kecil. Hal ini berarti perusahaan sampel memiliki ROE yang cenderung rendah dilihat dari nilai ROE perusahaan sampel mendekati rata-rata dan variasinya semakin kecil.

EPS mempunyai nilai rata-rata dari hasil uji statistik deskriptif adalah sebesar 0,31 . Standar deviasi sebesar 0,65 yang menunjukkan tingkat persebaran data semakin menjauhi rata-rata. Nilai terendah sebesar $-0,97$ atau $-97 \%$ dan nilai tertinggi sebesar 3,30. Hal ini berarti EPS memiliki rata-rata sebesar 0,31 atau 31\% dengan standar deviasi 
sebesar 0,65 atau $65 \%$. Nilai ini menunjukkan bahwa data semakin menjauhi nilai ratarata dan variasi penyebarannya semakin besar. Adanya nilai EPS yang menjauhi rata-rata menunjukkan bahwa nilai EPS perusahaan sampel cenderung besar karena nilai EPS perusahaan sampel berada di atas nilai rata-rata.

NPM mempunyai nilai rata-rata dari hasil uji statistik deskriptif adalah sebesar 0,22 atau $22 \%$. Standar deviasi sebesar 0,88 atau $88 \%$ yang menunjukkan tingkat persebaran data semakin menjauhi rata-rata. Nilai terendah sebesar $-0,70$ atau $-70 \%$ dan nilai tertinggi sebesar Rp 3,3. Hal ini berarti NPM memiliki rata-rata sebesar 0,22 atau $22 \% 3$ dengan standar deviasi sebesar 0,88 atau 88\%5. Nilai ini menunjukkan bahwa data semakin menjauhi nilai rata-rata dan variasi penyebarannya semakin besar. Adanya nilai NPM yang menjauhi rata-rata menunjukkan bahwa nilai NPM perusahaan sampel cenderung besar karena nilai NPM perusahaan sampel berada di atas nilai rata-rata.

DER mempunyai nilai rata-rata dari hasil uji statistik deskriptif adalah sebesar 0,27 atau $27 \%$. Standar deviasi sebesar 0,27 atau $27 \%$ yang menunjukkan tingkat persebaran data semakin menjauhi rata-rata. Nilai terendah sebesar 0 dan nilai tertinggi sebesar 0,84 atau 84\% tahun.. Nilai ini menunjukkan bahwa data semakin menjauhi nilai rata-rata dan variasi penyebarannya semakin besar. Adanya nilai DER yang menjauhi rata-rata menunjukkan bahwa nilai NPM perusahaan sampel cenderung besar karena nilai DER perusahaan sampel berada di atas nilai rata-rata.

CR mempunyai nilai rata-rata dari hasil uji statistik deskriptif adalah sebesar 0,11 atau $11 \%$. Standar deviasi sebesar 0,21 atau $21 \%$ yang menunjukkan tingkat persebaran data semakin menjauhi rata-rata. Nilai terendah sebesar 0 dan nilai tertinggi sebesar 0,76. Nilai ini menunjukkan bahwa data semakin menjauhi nilai rata-rata dan variasi penyebarannya semakin besar. Adanya nilai CR yang menjauhi rata-rata menunjukkan bahwa nilai CR perusahaan sampel cenderung besar karena nilai CR perusahaan sampel berada di atas nilai rata-rata.

Metode regresi linear berganda, yaitu metode yang digunakan untuk menguji pengaruh dua atau lebih variabel independen terhadap variabel dependen dengan skala pengukur atau rasio dalam suatu persamaan linier. Variabel independen dalam penelitian ini adalah ROA, ROE, EPS, NPM DER dan CR. Sedangkan variabel independennya adalah Return Saham. 
Tabel 3. Hasil Analisis Regresi Linear Berganda

\begin{tabular}{|c|c|c|c|c|c|}
\hline \multirow{2}{*}{ Model } & \multicolumn{2}{|c|}{$\begin{array}{c}\text { Unstandardized } \\
\text { Coefficients }\end{array}$} & $\begin{array}{c}\text { Standardized } \\
\text { Coefficients }\end{array}$ & \multirow{2}{*}{$\mathrm{t}$} & \multirow{2}{*}{ Sig. } \\
\cline { 2 - 4 } & $\mathrm{B}$ & Std. Error & Beta & & \\
\hline (Constant) & 1,642 & 1,890 & & 0,869 & 0,410 \\
ROA (X1) & $-9,672$ & 10,184 & $-0,412$ &,- 950 & 0,370 \\
Ln ROE (X2) & 0,293 & 0,353 & 0,563 & 0,830 & 0,430 \\
EPS (X3) & 0,198 & 0,150 & 0,828 & 5,554 & 0,016 \\
Ln NPM (X4) & $-0,216$ & 0,339 & $-0,361$ & $-0,636$ & 0,543 \\
DER (X5) & $-0,579$ & 0,007 & $-0,037$ & $-5,093$ & 0,031 \\
Ln CR (X6) & 0,193 & 0,258 & 0,426 & 0,748 & 0,476 \\
\hline
\end{tabular}

Konstanta sebesar 1,642 mengartikan bahwa jika variabel ROA, ROE, EPS dan NPM DER dan Current Ratio konstan atau nol (X1, X2, X3, X4, X5 dan X6 =0) maka Return Saham sebesar 1,642 yang bersifat positif. 1). ROA (X1) terhadap return saham (Y) Koefisien regresi ROA sebesar $-9,672$ berarti hubungan antara ROA dengan return saham berlawanan jika ROA naik maka return saham akan turunk dan sebaliknya dengan asumsi $\mathrm{x} 1, \mathrm{x} 2, \mathrm{x} 3, \mathrm{x} 4, \mathrm{x} 5=0,2)$. ROE (X2) terhadap return saham (Y) Koefisien regresi ROE sebesar 0,293 berarti hubungan antara ROE dengan return saham searah, jika ROE naik maka return saham akan naik dan sebaliknya x1, x2, x3, x4, x5 = 0, 3). EPS (X3) terhadap return saham (Y) Koefisien regresi EPS sebesar 0,198 berarti hubungan antara EPS dengan return saham searah, jika EPS naik maka return saham akan naik dan sebaliknya $x 1, x 2, x 3, x 4, x 5=0,4)$. NPM (X4) terhadap return saham (Y) Koefisien regresi NPM sebesar $-0,216$ berarti hubungan antara NPM dengan return saham tidak searah, jika NPM naik maka return saham akan turun dan sebaliknya $\mathrm{x} 1, \mathrm{x} 2, \mathrm{x} 3, \mathrm{x} 4, \mathrm{x} 5=0,5)$. DER (X5) terhadap return saham (Y) Koefisien regresi DER sebesar -0,579 berarti hubungan antara DER dengan return saham tidak searah, jika DER naik maka return saham akan turun dan sebaliknya $\mathrm{x} 1, \mathrm{x} 2, \mathrm{x} 3, \mathrm{x} 4, \mathrm{x} 5=0,6)$. Current Ratio (X6) terhadap return saham (Y) Koefisien regresi CR sebesar 0,193 berarti hubungan antara CR dengan return saham searah, jika CR naik maka return saham akan naik dan sebaliknya x1, x2, x3, x4, x5 =0

Berdasarkan hasil analisis regresi berganda pada Tabel 3 dengan uji t diperoleh hasil sebagai berikut. 1). Pengaruh ROA terhadap Return Saham, ROA memiliki tingkat signifikansi (sig t) sebesar 0,370 Nilai ini lebih dari $\alpha(=0,05)$, maka hipotesis pertama yang menyatakan ROA berpengaruh signifikan terhadap Return Saham ditolak. Artinya, ROA tidak berpengaruh terhadap Return Saham pada perusahaan yang terdaftar di Bursa Efek Syariah. ROA tidak berpengaruh terhadap Return Saham artinya setiap peningkatan atau penurunan variabel ROA tidak memiliki pengaruh terhadap peningkatan dan penurunan Return Saham. 2). Pengaruh ROE perusahaan terhadap Return Saham, ROE memiliki tingkat signifikansi (sig t) sebesar 0, 430 dengan tanda positif. Nilai ini lebih dari $\alpha(=0,05)$, maka hipotesis kedua yang menyatakan ROE berpengaruh signifikan terhadap 
Return Saham ditolak. Artinya, ROE tidak berpengaruh signifikan terhadap Return Saham pada perusahaan yang terdaftar di Bursa Efek Syariah. ROE tidak berpengaruh signifikan terhadap Return Saham artinya setiap peningkatan atau penurunan ROE tidak berpengaruh terhadap peningkatan Return Saham. 3). Pengaruh EPS Perusahaan terhadap Return Saham, EPS memiliki tingkat signifikansi (sig t) sebesar 0,016 dengan tanda koefisien positif ini kurang dari $\alpha(=0,05)$, maka hipotesis ketiga yang menyatakan EPS berpengaruh signifikan terhadap Return Saham diterima. Artinya, EPS berpengaruh signifikan terhadap Return Saham pada perusahaan yang terdaftar di Bursa Efek Syariah. EPS berpengaruh signifikan terhadap Return Saham artinya setiap peningkatan atau penurunan EPS berpengaruh terhadap peningkatan dan penurunan Return Saham. 4). Pengaruh NPM Perusahaan terhadap Return Saham, NPM memiliki tingkat signifikansi (sig t) sebesar 0,543 dengan tanda koefisien positif ini lebih dari $\alpha(=0,05)$, maka hipotesis keempat yang menyatakan NPM berpengaruh signifikan terhadap Return Saham ditolak. Artinya, NPM tidak berpengaruh signifikan terhadap Return Saham pada perusahaan yang terdaftar di Bursa Efek Syariah. NPM tidak berpengaruh signifikan terhadap Return Saham artinya setiap peningkatan atau penurunan NPM tidak berpengaruh terhadap peningkatan dan penurunan Return Saham. 5). Pengaruh DER Perusahaan Perusahaan terhadap Return Saham, DER memiliki tingkat signifikansi (sig t) sebesar 0,031 dengan tanda koefisien positif ini kurang dari $\alpha(=0,05)$, maka hipotesis kelima yang menyatakan DER berpengaruh signifikan terhadap Return Saham diterima. Artinya, DER berpengaruh signifikan terhadap Return Saham pada perusahaan yang terdaftar di Bursa Efek Syariah. DER berpengaruh signifikan terhadap Return Saham artinya setiap peningkatan atau penurunan DER berpengaruh terhadap peningkatan dan penurunan Return Saham. 6). Pengaruh CR Perusahaan Perusahaan terhadap Return Saham, CR memiliki tingkat signifikan sebesar 0,476 dimana lebih dari $\alpha(=0,05)$, maka hipotesis keenam yang menyatakan CR berpengaruh signifikan terhadap Return Saham ditolak Artinya, CR tidak berpengaruh signifikan terhadap Return Saham pada perusahaan yang terdaftar di Bursa Efek Syariah. CR tidak berpengaruh signifikan terhadap Return Saham artinya setiap peningkatan atau penurunan CR tidak berpengaruh terhadap peningkatan dan penurunan Return Saham.

Berdasarkan analisis data maka dapat dijelaskan masing-masing pengaruh ROA, ROE, EPS, NPM DER dan CR terhadap Return Saham seperti dijelaskan berikut.

\section{Pengaruh Profitabilitas dengan Return Saham}

Hasil pengujian menunjukkan bahwa ROA tidak berpengaruh signifkan terhadap return saham. Hal ini menunjukkan bahwa hipotesis pertama yang menyatakan bahwa ROA berpengaruh terhadap return saham, ditolak. Return on Assets (ROA) menggambarkan perputaran aktiva diukur dari volume penjualan. Semakin besar rasio ini semakin baik. Hal ini berarti bahwa aktiva dapat lebih cepat berputar dan meraih laba 
. Adanya peningkatan pengembalian aset menunjukkan seberapa baik aset dikelola oleh perusahaan untuk mendatangkan keuntungan bagi setiap satu dolar aset yang telah diinvestasikan ke perusahaan. ${ }^{51}$

ROA tidak berpengaruh signifikan terhadap return saham. Hal tersebut kemungkinan terjadi karena perusahaan sektor keuangan memiliki data komponen ROA yaitu laba setelah pajak dan total asset yang tidak stabil pada setiap tahun selama periode 20182020. Faktornya adalah investor tidak hanya memperhatikan kemampuan internal perusahaan dalam menghasilkan keuntungan investasinya tetapi memperhatikan risiko eksternal serta kondisi pasar. Risiko eksternal dapat berupa inflasi, kenaikan tarif, perubahan kebijakan ekonomi, kenaikan beban pokok penjualan, depresiasi yang lebih tinggi, serta politik. Permintaan dan penawaran di pasar modal juga berpengaruh dalam kepuausan investasi yang dapat mengakibatkan fluktuasi harga dan return saham. Jadi besar kecilnya ROA tidak serta merta mempengaruhi tinggi rendahnya return saham, artinya perusahaan kurang maksimal dalam pengelolaan asset untuk menghasilkan laba. Hasil ini tidak sesuai dengan penelitian Saputro menunjukkan bahwa ROA berpengaruh positif dan signifikan terhadap pengembalian saham. 52

Hasil pengujian menunjukkan bahwa ROE tidak berpengaruh signifkan terhadap return saham. Hipotesis kedua yang menyatakan bahwa ROE berpengaruh signifkan terhadap return saham, ditolak. Hal itu menunjukka bahwa semakin tinggi ROE tidak menentukan return saham. Variabel Return On Equity (ROE) tidak berpengaruh secara signifikan terhadap return saham menandakan bahwa perusahaan tidak dapat menjamin ekuitasnya dengan laba. Perusahaan yang masih berukuran kecil memiliki nilai ROE yang cenderung meningkat dengan cepat sejalan dengan peningkatan laba bersih (earning). Hal itu menyebabkan regresi linier dengan sample perusahaan yang mempunyai fase pertumbuhan yang berbeda memberikan hasil yang tidak signifikan. Hasil penelitian ini tidak mendukung penelitian Yustini menemukan bahwa ROE berpengaruh positif terhadap Return saham. ${ }^{53}$

Hasil pengujian menunjukkan bahwa EPS berpengaruh signifkan terhadap return saham. Hal ini menunjukkan bahwa hipotesis ketiga yang menyatakan bahwa NPM berpengaruh signifkan terhadap return saham, diterima. Earning Per Share (EPS) merupakan rasio yang menunjukkan berapa besar kemampuan per lembar saham menghasilkan laba. Earning Per Share (EPS) mengukur keberhasilan manajemen dalam

51 Aryono, Yokobus dan Isworo, Sri Ediningsih. 2009. Pengaruh Right Issue Terhadap Kinerja Keuangan Pada Perusahaan Yang Terdaftar di Bursa Efek Indonesia", Call For Paper Hasil - Hasil Penelitian Dosen dan Seminar Nasional, hal $310-328$.

${ }^{52}$ Loc.cit. Saputro 2018. Hal.45

${ }^{53}$ Yustini, Santi, Yusar Sagara, dan Anis Saputri.2018. The Effect Of Profitability, Value, Size and Managerial Discretion On Disclourse Of Stock Return. Akutabilitas IImu Akuntansi. Volume 11 No 1. Hal 12-37 
mencapai keuntungan bagi pemegang saham. Hal tersebut terjadi karena EPS pada perusahaan sub sektor keuangan yang stabil pada setiap tahun selama periode 20182020. Dalam memperdagangkan saham, laba per saham dapat mempengaruhi return saham, karena tujuan para investor dalam berinvestasi adalah memaksimalkan return. Ini menunjukkan bahwa perusahaan perusahaan sub sektor keuangan menunjukan kinerja perusahaan yang produktif untuk memperoleh aktiva dan laba per saham serta kemampuan perusahaan yang baik dalam menekan biaya-biaya operasionalnya sehingga mampu menghasilkan keuntungan. Semakin tinggi kemampuan perusahaan untuk mendistribusikan pendapatan (return) kepada pemegang saham, mencerminkan semakin besar keberhasilan usaha yang dilakukan perusahaan Hasil penelitian ini sesuai dengan penelitian Sodikin dan Wuldani menemukan bahwa EPS berpengaruh psoitif terhadap Return saham. ${ }^{54}$ Dengan demikian, Semakin tinggi nilai EPS, kesejahteraan pemegang saham meningkat, tingkat pengembalian yang tinggi.

Hasil pengujian menunjukkan bahwa NPM tidak berpengaruh signifkan terhadap return saham. Hal ini menunjukkan bahwa hipotesis empat yang menyatakan bahwa NPM berpengaruh signifkan terhadap return saham, ditolak. Net Profit margin digunakan untuk mengukur margin laba atas penjualan. besar rasio ini semakin baik karena dianggap kemampuan perusahaan dalam mendapatkan laba cukup tinggi. Hal tersebut menunjukkan bahwa perusahaan sektor keuangan di Bursa Efek Syariah menunjukan kinerja perusahaan yang kurang pendapatan tertentu serta kemampuan perusahaan yang kurang baik dalam menekan biaya-biaya operasionalnya sehingga mampu menghasilkan keuntungan bersih. Sehingga investor mempertimbangkan keputusannya untuk menginvestasikan modalnya pada perusahaan tersebut sehingga permintaan akan saham perusahaan menurun yang otomatis akan diikuti penurunan return saham tersebut. Hal tersebut kemungkinan terjadi karena sektor keuangan di Bursa Efek Syariah memiliki data komponen NPM yaitu laba setelah pajak dan penjualan bersih yang tidak stabil pada setiap tahun selama periode 2018-2020. Hasil ini tidak konsisten dengan Darmawan (2012), Aryanti (2016) dan Darmawati (2017) menemukan bahwa NPM berpengarih terhadap Return saham. Dengan demikian, semakin tinggi nilai Profit Margin suatu perusahaan maka semakin tinggi Return saham.

\section{Pengaruh Leverage dengan Return Saham}

Hasil pengujian menunjukkan bahwa DER berpengaruh negatif dan signifkan terhadap return saham. Hal ini menunjukkan bahwa hipotesis lima yang menyatakan bahwa current ratio berpengaruh signifkan terhadap return saham, diterima. Debt to Equity Ratio (DER) yang digunakan untuk mengetahui berapa besar untung yang dimiliki

\footnotetext{
${ }^{54}$ Sodikin, S \& Wuldani, N (2016). Pengaruh Price Earning Ratio (Per) Dan Earning Per Share (Eps) Terhadap Return Saham (Studi Pada Pt. Unilever Indonesia Tbk.) Jurnal Ekonomi Manajemen Universitas Siliwangi Vol 2. No. 1, Mei 2016. Hal. 18-25
} 
perusahaan bila dibandingkan dengan ekuitasnya. Debt to Equity Ratio (DER) yang tinggi mencerminkan risiko solvabilitas perusahaan yang relatif tinggi dan sebagai akibatnya, investor cenderung menghindari perusahaan dengan hutang tinggi atau perusahaan yang memiliki DER tinggi. Hal itu menunjukkan bahwa DER yang tinggi justru menurunkan return saham

Kondisi ini mengandung arti bahwa semakin rendah Debt to Equity Ratio menunjukkan semakin kecil ketergantungan perusahaan terhadap pihak luar sehingga tingkat resiko perusahan semakin kecil. Oleh sebagian investor DER dipandang sebagai besarnya tanggung jawab perusahaan terhadap pihak ketiga yaitu kreditor yang memberikan pinjaman kepada perusahaan. DER yang terlalu tinggi mempunyai dampak buruk terhadap kinerja perusahaan, karena dengan tingkat uatng yang semakin tinggi berarti beban tetap perusahaan akan semakin besar dan akan mengurangi keuantungan. Dengan tingkat utang yang tinggi dan dibebankan kepada pemegang saham, tentu akan meningkatkan resiko investasi kepada para pemegang saham.

Hasil ini konsisten dengan penelitian Febriawan dan Santosa, menunjukkan DER berpengaruh signifikan terhadap return saham. ${ }^{55}$

\section{Pengaruh Likuiditas dengan Return Saham}

Berdasarkan Hasil pengujian menunjukkan bahwa pengaruh yang diberikan oleh variabel CR terhadap return saham adalah tidak signifikan. Hal ini menunjukkan bahwa hipotesis enam yang menyatakan bahwa current ratio berpengaruh signifkan terhadap return saham, ditolak. Kondisi ini mengandung arti bahwa CR yang rendah biasanya dianggap menunjukkan terjadinya masalah dalam likuiditas dan merupakan indikator awal mengenai ketidakmampuan perusahaan untuk memenuhi kewajiban jangka pendeknya. CR yang tinggi, yang berarti likuiditas yang tinggi juga menunjukkan bahwa perusahaan kurang mampu mengelola money to create money, yang pada akhirnya dapat mengurangi kemampulabaan perusahaan.

Investor sering menilai bahwa semakin besar CR menunjukkan besarnya kemampuan perusahaan dalam memenuhi kebutuhan operasionalnya terutama modal kerja yang sangat penting untuk menjaga perfomance kinerja perusahaan yang pada akhirnya mempengaruhi performance harga saham. Hal ini dapat memberikan keyakinan kepada investor untuk memiliki saham perusahaan tersebut sehingga dapat

\footnotetext{
${ }^{55}$ Loc.cit. Febriawan dan Santosa.2018. Hal. 7
} 
meningkatkan return saham. Hasil penelitian ini tidak konsisten dengan Latifah dan Laila yang menyatakan bahwa current ratio berpengaruh signifkan terhadap return saham. ${ }^{56}$

\section{KESIMPULAN}

Berdasarkan hasil analisis data disimpulkan hal-hal yaitu 1) Rasio profitabilitas yaitu ROA tidak berpengaruh signifkan terhadap return saham. ROE tidak berpengaruh signifkan terhadap return saham. EPS berpengaruh signifkan terhadap return saham. NPM tidak berpengaruh signifkan terhadap return saham; 2) Leverage yang diproksikan DER berpengaruh negatif dan signifkan terhadap return saham; 3) Rasio likuiditas yang diukur Current ratio menunjukkan bahwa pengaruh yang diberikan oleh variabel Current ratio terhadap return saham adalah tidak signifikan. Hal ini menunjukkan bahwa hipotesis enam yang menyatakan bahwa current ratio berpengaruh signifkan terhadap return saham, ditolak. Current Ratio yang meningkat tidak dapat meningkatkan return saham.

Berdasarkan hasil penelitian maka disarankan yaitu 1) bagi Investor dan calon investor, dapat dijadikan sebagai referensi untuk mengetahui dan mempertimbangkan faktor- faktor yang mempengaruhi dalam return saham; 2) Bagi perusahaann hendaknya meningkatkan EPS dan menurunkan DER atau hutang dengan mencari sumber dana lain yang kecil risiko bagi perusahaan dan 3) Bagi peneliti selanjutnya diharapkan menambah rasio keuangan sebagai variabel independen, karena sangat memungkinkan rasio keuangan lain yang tidak dimasukkan dalam penelitian ini berpengaruh terhadap Return saham dan dapat memperpanjang periode pengamatan agar mendapatkan hasil penelitian yang lebih valid. Beberapa variabel tidak terbukti dalam penelitian ini, sebaiknya penelitian selanjutnya menggunakan proksi rasio lain untuk Likuiditas, Solvabilitas dan Profitabilitas. Contohnya untuk profitabilitas bisa menggunakan rasio PER, MBV, rasio pasar dan sebagainya. Selain itu, jumlah sampel yang terlalu minim hendaknya diperluas pada sektor lain yang terdaftar di Bursa Syariah seperti Jakarta Islamic Indeks dan lain-lain

\section{DAFTAR PUSTAKA}

Anugrah, Agung dan Syaichu, Muhamad. 2017. Analisis Pengaruh Return On Equity, Debt To Equity Ratio, Current Ratio, Dan Price To Book Value Terhadap Return Saham Syariah (Studi Kasus Pada Perusahaan Yang Terdaftar Dalam Jakarta Islamic Index Periode 2011-2015 ). Diponegoro Journal of Management Volume 6, Nomor 1, Tahun 2017

${ }^{56}$ Latifah, N.A. 2017. Pengaruh Return On Equity, Earning Per Share, Dan Debt To Equity Ratio Terhadap Return Saham (Studi Pada Emiten Saham Syariah Sektor Property Dan Real Estate Yang Terdaftar di ISSI Tahun (2013 - 2015). Jurnal Ekonomi Syariah Teori dan Terapan Vol. 4 No. 12 Desember Hal. 1009-1023 
Arianto, Tulus. 2009. Struktur Kepemilikan, Profitablitas, Pertumbuhan Aktiva, Dan Ukuran Perusahaan Terhadap Struktur Modal Pada Perusahaan Manufaktur Jurnal Keuangan dan Perbankan, Vol 12, No. 1. Program Studi Keuangan dan Perbankan, Universitas Merdeka Malang.

Arista dan Astohar. 2012. Analisis Faktor-faktor yang Mempengaruhi Return Saham (Kasus pada Perusahaan Manufaktur yang Go Public di BEI periode tahun 20052009). Jurnal Ilmu Manajemen dan Akuntansi Terapan, Vol. 3, No. 1, Mei 2012.

Aryanti Aryanti dan Mawardi Mawardi . 2016. Pengaruh ROA, ROE, NPM dan CR Terhadap Return Saham Pada Perusahaan Yang Terdaftar Di Jakarta Islamic Index (JII). Journal article I-Finance $\bullet 2016$

Aryono, Yokobus dan Isworo, Sri Ediningsih. 2009. Pengaruh Right Issue Terhadap Kinerja Keuangan Pada Perusahaan Yang Terdaftar di Bursa Efek Indonesia", Call For Paper Hasil - Hasil Penelitian Dosen dan Seminar Nasional, hal 310 -328.

Astohar, 2010, P engaruh Return On Asset, Debt to Equity Ratio, Price to Book Value dan Earning Per Share Terhadap Return Saham Pada Perusahaan Manufaktur Di Bursa Efek Indonesia. Eksplanasi, Vol.5, No.2 : 79-88

Atidhira, Agung Tri dan Yustina, Andi 2017. The Influence of Return on Asset, Debt to Equity Ratio, Earnings per Share, and Company Size on Share Return in Property and Real Estate Companies. AAF (Journal of Applied Accounting and Finance). Vol. 1. No. 2, page 128-146

Bhandari, L. 1988. Debt/Equity Ratio and Expected Common Share Returns: Empirical Evidence. The Journal of Finance, 43(2), 507-528.

Brigham, E. F., \& Houston, J. F. 2015. Fundamentals of Financial Management (13th edition ed.). Ohio: South-Western Cengage Learning

Budiman, Raymond. 2017. Investing is Easy, Teknik Analisa dan Strategi Investasi Saham untuk Pemula. Jakarta: Elex Media Komputindo.

Bur, F.I., Munthe, I.L.S \& Ratih, A.E. 2018. Pengaruh Return On Equity, Debt To Equity Ratio, Price Earning Ratio dan Beta terhadap Return Saham Perusahaan Manufaktur Sektor Industri Food dan Beverages di Bursa Efek Indonesia Tahun 2013-2016. Artikel Fakultas Ekonomi UMRAH, Agustus, 2018: 1-16.

Dermawan, Deni. 2014. Metode Penelitian Kuantitatif. Cetakan Kedua. Bandung: PT. Remaja Rosdakarya.

Ekawati, Erni. 2015. Manajemen Keuangan. Tangerang Selatan: Universitas Terbuka. 
Eliana 2017. Pengaruh Return On Equity Terhadap Return Saham (Studi Pada Perusahaan Manufaktur periode 2012-2015 di Bursa Efek Indonesia). Jurnal Akuntansi dan Manajemen STIES Banda Aceh Vol.8 No.2 Desember 2017

Fahmi, Irham. 2014. Analisis Laporan Keuangan. Cetakan Ke-2. Bandung: Alfabeta

Febriawan, M \& Santosa, PW. (2017). Return Saham Dan Faktor Fundamental Pada Pra Krisis Ekonomi Global 2008 Di Bursa Efek Indonesia. Journal of Economics and Business Aseanomics (JEBA) Universitas YARSI Vol.2 No.2 Juli-Desember. 2017:232248.

Filbert, Ryan \& Prasetya, William. 2017. Investasi Saham ala Fundamentalis Dunia. Jakarta: Elex Media Komputindo.

Ghozali, Imam. 2016. Aplikasi Analisis Multivariete Dengan Program IBM SPSS 23 (Edisi 8). Semarang: Badan Penerbit Universitas Diponegoro.

Hani, Syafrida.2015. Teknik Analisa Laporan Keuangan. Medan: UMSU PRESS

Harahap, S.S. 2015. Analisis Kritis atas Laporan Keuangan. Jakarta: Rajawali Pers.

Hardiningsih, Pancawati, Suryanto, L. Chariri, \& Anis. (2002). Pengaruh Faktor Fundamental dan Risiko Ekonomi Terhadap Return Saham Pada Perusahaan di Bursa Efek Jakarta (Studi Kasus Basic Industry dan Chemical), Jurnal Strategi Bisnis, 8(4), 83-96

Harjito, Agus dan Martono, 2011. Manajemen Keuangan, Edisi Kedua, Cetakan. Pertama, Penerbit EKONISIA, Yogyakarta

Hermawan, Ahmadi , 2013. E-Business \& E-Commerse. Andi: Denpasar.

Hogan, Nicky. 2017. Yuk Belajar Saham untuk Pemula. Jakarta: Elex Media Komputindo.

Ichsani, Sakina dan Agatha Rinta Suhardi. 2015. The effect of Return On Equity (ROE) and Return on Investment on Trading Volume. Global Conference on Business and Social Science-2015, GCBSS-2105. Nd

Janie, D.N.H. 2012. Statistik Deskriptif \& Regresi Linier Berganda dengan SPSS. Semarang: Semarang University Press.

Jhony, Kurniawan, Yohanes .2013. Analisis Pengaruh Earning Per Share (EPS), Debt To Equity Ratio (DER), Return On Asset (ROA), Return On Equity (ROE) Terhadap Return Saham (Studi Empirik Pada Perusahaan Real Estate Dan Property Yang Terdaftar Di Bursa Efek Indonesia (BEI) Dalam Pengamatan 2008 - 2011) Jurnal Akuntansi, Bandung : Universitas Widyatama..

Jumingan, 2006. Analisis Laporan Keuangan, Cetakan Pertama, PT Bumi Aksara,. Jakarta Kasmir. 2016. Analisis Laporan Keuangan. Jakarta: Rajawali Pers. 
Kennedy J.S.P. 2003. Analisis Pengaruh dari Return on Asset, Return on Equity, Earnings Per Share, Profit Margin, Asset Turnover, Rasio Leverage dan Debt to Equity Ratio terhadap Return Saham (Studi terhadap Saham-saham yang Termasuk dalam LQ-45 di BEJ Tahun 2001). Tesis tidak dipublikasikan, Program Pascasarjana Universitas Indonesia, Jakarta.

Kieso et al., 2011. Intermediate Accounting. Jilid.1 Edisi 12. Jakarta. Erlangga

Kumar, S., dan Warne, D. 2014. Parametric Determinants of Price-Earnings Ratio in Indian Capital Markets. The IUP Journal of Applied Finance, 15(9), 63-82.

Latifah, N.A. 2017. Pengaruh Return On Equity, Earning Per Share, Dan Debt To Equity Ratio Terhadap Return Saham (Studi Pada Emiten Saham Syariah Sektor Property Dan Real Estate Yang Terdaftar di ISSI Tahun (2013 - 2015). Jurnal Ekonomi Syariah Teori dan Terapan Vol. 4 No. 12 Desember 2017: 1009-1023.

Lestari, W.D. \& Dewi, Rosita. 2018. Pengaruh Return On Asset (ROA), Debt To Equity Ratio (DER), Priceto Book Value (PBV), Dan Price Earning Ratio (PER) Terhadap Return Saham (Studi Pada Perusahaan Yang Tercantum Dalam LQ45 di BEI Tahun 20142016). Prosiding, Universitas Muhamdiyah, Surakarta.

Majelelis Ulama Indonesia. Fatwa Dewan Syariah Nasional tentang Penerapan Prinsip Syariah dalam Mekanime Perdagangan Efek Bersifat Ekuitas di Pasar Reguler Bursa Efek. No. 80 tahun 2011.

Nguyen, Hoa, dan Robert Faff .2014. Impact Of Board Size And Board Diversity On Firm Value: Australian Evidence. Corporate Ownership \& Control. Vol. 4, Issue 2, 'Winter 2006-2007.

Otoritas Jasa Keuangan. Keputusan Dewan Komisioner tentang Daftar Efek Syariah (DES). Kep-24/D.04/2018

Pasaribu, Rowland. 2009. Pengaruh Variabel Fundamental Terhadap Harga Saham Perusahaan Go Public di Bursa Efek Indonesia (BEI) Periode 2003-2006. Jurnal Ekonomi dan Bisnis, 2(2): h:101-113.

Rahmawati, Ani. 2017. Pengaruh Earning Per Share (EPS) Return On Equity (ROE) dan Debt to Equity Ratio (DER) terhadap Return Saham Pada Perusahaan Food And Beverages yang Terdaftar di Bursa Efek Indonesia Periode 2011-2015. Jurnal Fakulas Ekonomi Universitas Pakuan.

Rianto, M.R. 2018. Implikasi Return On Equity, Return On Asset, Net Income \& Debt To Equity Ratio Terhadap Return Saham Pada Perusahaan Properti. Jurnal Riset Manajemen dan Bisnis (JRMB) Fakultas Ekonomi UNIAT Vol.3, No.1, Februari 2018: $59-66$. 
Saputro, Retno. 2018. Pengaruh Return On Assets, Debt To Equity Ratio, dan Current Ratio Terhadap Return Saham Pada Perusahaan Manufaktur Yang Terdaftar di Bursa Efek Indonesia Periode 2011-2015. Jurnal Akuntansi Universitas Maritim Raja Ali Haji.Vol.1 No.3 Hal. 12-24

Sodikin, S \& Wuldani, N (2016). Pengaruh Price Earning Ratio (Per) Dan Earning Per Share (Eps) Terhadap Return Saham (Studi Pada Pt. Unilever Indonesia Tbk.) Jurnal Ekonomi Manajemen Universitas Siliwangi Vol 2. No. 1, Mei 2016: 18-25.

Sreemoyee. 2013. Business Analysis \& Valuation: Using Financial Statements (4ed.). Mason: South-Western Cengage Learning

Sujarweni, V.W. 2017. Analisis Laporan Keuangan, Teori, Aplikasi, dan Hasil Penelitian. Yogyakarta: Pustaka Baru Press.

Suresh. A.S,.2013. A Study on Fundamental and Technical Analysis. International Journal of Marketing, Financial Services \& Management Research ISSN 2277- 3622 Vol.2, No. 5

Tandelin, Eduardus. 2016. Manajemen Investasi. Tangerang Selatan: Universitas Terbuka.

Tumonggor, Mutiara. Sri Murni dan Rate, Paulina Van. 2017. Analisis Pengaruh Current Ratio, Return On Equity, Debt To Equity Ratio dan Growth Terhadap Return Saham Pada Cosmetics And Household Industry Terdaftar Di Bei Periode 2010-2016.Jurnal EMBA Vol.5 No.2 Juni 2017, Hal. 2203 - 2210

Venkatesh, C.K. dan Tyagi, M. 2011. Fundamental Analysis As A Method Of Share Valuation Comparison With Technical Analysis, Bangladesh Research Publication Journal , 5(3), $167-174$

Voloshyna, K. 2015. Fundamental Analysis Vs Technical Analysis in The Egyptian Stock Exchange-Empirical Study. International Journal of Business and Management Study-IJBMS,2(2), 212- 218

Yuni Nur Aryaningsih, Y.N., Fathoni, Azis, \&, Harini, Cicik. 2018. Pengaruh Return On Asset (ROA), Return On Equity (ROE) dan Earning Per Share (EPS) Terhadap Return Saham Pada Perusaahan Consumer Good (Food And Beverages) Yang Terdaftar di Bursa Efek Indonesia (BEI) Periode 2013-2016. Jurnal Manajemen Universitas Pandanaran Vol.4 No.4 April 2018.

Yustini, Santi, Yusar Sagara, dan Anis Saputri.2018. The Effect Of Profitability, Value, Size and Managerial Discretion On Disclourse Of Stock Return. Akutabilitas Ilmu Akuntansi. Volume 11 No 1. Hal.121-129 